\title{
ROLE OF HBA1C AND HS-CRP IN TYPE 2 DIABETES MELLITUS WITH CARDIOVASCULAR DISEASES
}

\author{
Pallavi Anand ${ }^{1}$, Manju Lata Arya², Vikas Kumar ${ }^{3}$, Renu Jain 4 , Jyotirmay 5 \\ ${ }_{1}^{1}$ Assistant Professor, Department of Biochemistry, Rama Medical College Hospital \& Research Centre, Kanpur, Uttar Pradesh. \\ ${ }^{2}$ Associate Professor, Department of Physiology, Rama Medical College Hospital \& Research Centre, Kanpur, Uttar Pradesh. \\ ${ }^{3}$ Assistant Professor, Department of Pathology, Rama Medical College Hospital \& Research Centre, Kanpur, Uttar Pradesh. \\ ${ }^{4}$ Professor \& HOD, Department of Pathology, Rama Medical College Hospital \& Research Centre, Kanpur, Uttar Pradesh. \\ ${ }^{5}$ Reader, Department of Orthodontics, Dr. B. R. Ambedkar Institute of Dental Sciences \& Hospital.
}

\section{ABSTRACT}

\section{BACKGROUND}

Important perspective studies on chronic complications of Diabetes Mellitus made it possible to establish with absolute certainty the role of glycated haemoglobin (HbA1c) as a marker of evaluation of long term glycemic control in diabetic patients and the strict relationship between the risk of chronic complications and HbA1c levels.

\section{OBJECTIVE}

This study was undertaken to assess the role of HbA1c in type 2 Diabetes Mellitus with cardiovascular disorders.

\section{MATERIAL AND METHOD}

This study was carried out in Department of Biochemistry, Katihar Medical College and Hospital, Bihar. Diabetic and non-diabetic subjects were selected from patients attending outdoor, indoor and ICU of Medicine Department and were investigated for HbA1c and hs-CRP.

\section{RESULTS}

The HbA1c was in normal range in non-diabetic subjects and significantly raised in diabetic patients. Among patients with cardiovascular complications, the HbA1c and hs-CRP were significantly raised indicating their positive correlation.

\section{CONCLUSION}

The lifestyle changes can dramatically reduce the incidence of diabetes and show the HbA1c and hs-CRP increase in both diabetic and non-diabetic individuals. Regardless of whether lifestyle changes are ultimately proven to reduce cardiovascular in our society, public health approaches to facilitate them urgently need to be implemented.

\section{KEYWORDS}

Diabetes Mellitus, hsCRP, HbA1c, Cardiovascular Disorders.

HOW TO CITE THIS ARTICLE: Pallavi Anand, Manju Lata Arya, Vikas Kumar, Renu Jain, Jyotirmay. "Role of Hba1c and HS-CRP in Type 2 Diabetes Mellitus with Cardio-Vascular Diseases.” Journal of Evolution of Medical and Dental Sciences 2015; Vol. 4, Issue 99, December 10; Page: 16407-16410, DOI: 10.14260/jemds/2015/2430

\section{INTRODUCTION}

Diabetes, description of which first appears 3000 years ago in the inscriptions of the Papyrus of Ebers in Egypt, is a metabolic disorder with inappropriate hyperglycemia either due to an absolute or relative deficiency of insulin secretion or reduction in the biologic effectiveness of insulin or both. The decreased uptake of glucose into muscle and adipose tissue leads to chronic extracellular hyperglycemia, which results in tissue damage and chronic vascular complications in both type 1 and 2 Diabetes Mellitus.[1] Previously, it was regarded as a relatively distinct disease entity, but in reality type 2 diabetes is often a much broader underlying disorders. $[2,3]$

This includes the metabolic syndrome (Sometimes called

Financial or Other, Competing Interest: None.

Submission 12-10-2015, Peer Review 13-10-2015,

Acceptance 02-12-2015, Published 08-12-2015.

Corresponding Author:

Dr. Pallavi Anand,

Assistant Professor,

Department of Biochemistry,

Rama Medical College,

Hospital and Research Centre, Kanpur.

E-mail: anandorpallavi@gmail.com

DOI:10.14260/jemds/2015/2430 syndrome X) a cluster of Cardiovascular Disease (CVD) risk factors that in addition to Impaired Glucose Tolerance (IGT) or diabetes includes hyperinsulinemia, dyslipidemia, hypertension, visceral obesity hypercoagulability and microalbuminuria.

The level of glycated hemoglobins in the blood is directly related to the average blood glucose levels over the lifespan of the haemoglobin in the circulation. Since the half life of red blood cells is about 120 days, a single determination of glycated haemoglobin reflects the average blood glucose level during the preceding 8 to 12 weeks.

The test is therefore a very good monitor for long-term ( 2 to 3 months) blood glucose control in patients with diabetes mellitus predicts risks for the developments and progression of diabetic complications. Tests of glycated haemoglobin are also inexpensive and can be done at any time of day. Moreover, randomized trials have clearly shown that decreasing the glycated hemoglobin level reduces these risks.[4,5] Elevated glycohemoglobin HbA1c is an established predictor for developing atherosclerosis beyond the risk associated with diagnosed diabetes.[6]

Epidemiological studies indicate that diabetes mellitus can accelerate atherosclerotic processes and increase the 
incidence of cardiovascular events and strokes.[7] It has been demonstrated that inflammation plays an important role in atherosclerosis. ${ }^{[8]}$ and in the pathogenetic mechanisms of some cardiovascular events. ${ }^{[9]}$

C-reactive protein was invented by Tillet and Francis in 1930 as a substance in the serum of patients with acute inflammation that reacted with the C-polysaccharide of Pneumococcus.[10] CRP is a plasma protein, an acute phase protein produced by the liver and by adipocytes.[11]

High concentrations of CRP mRNA have been demonstrated to be present in atherosclerotic plaques.[12] Two research groups revealed independently that CRP is produced by human artery smooth muscle cells of atherosclerotic lesions in response to inflammatory cytokines.[13,14] Taking all this evidence into account, locally produced CRP may actually participate directly in aspects of atherogenesis, promoting the development of cardiovascular complications.

Measurement of hs-CRP should be done twice, optimally 2 weeks apart, to provide a more stable estimate of level of this marker.

Changes in human behaviour and lifestyle over the last century have resulted in a dramatic increase in the incidence of diabetes worldwide. The diabetes epidemic relates particularly to type 2 diabetes and is taking place both in developed and developing nations. ${ }^{[2]}$

With this background of knowledge, we aim to study the role of HbA1c in type 2 diabetes and its cardiovascular complications.

\section{MATERIALS AND METHODS}

The present study was undertaken in the Department of Biochemistry, Katihar Medical College and Hospital [KMCH], Bihar. The study was started in December 2009 and completed in May 2011. The subjects for the study group were selected from patients attending the outdoor, indoor and ICU of Medicine Department of KMCH. The subjects for the control group were selected from healthy persons accompanying patients from the same region. All subjects were informed about the risks and benefits of the study. Written consents were taken before blood was drawn. The study was approved by the Institute Ethics Committee.

In the present study, 70 cases of diabetes type 2 with or without complications were selected from different age groups. The diagnosis of diabetes mellitus was made on the basis of history, physical examination and blood glucose levels. The patients with complications were selected on the basis of clinical findings. The patients with cardiovascular complications were tested for hs-CRP. All subjects were tested for HbA1c. The same number of healthy subjects (70 in number) was also tested for the above parameters. Blood was drawn with aseptic precautions from the antecubital vein after over-night fasting. Separate aliquots were prepared for estimation of blood glucose, $\mathrm{HbA1} \mathrm{c}$ and hs-CRP using serum as the sample.

Quantitative determination of glucose in serum/plasma

Method-Glucose oxidase and peroxidase

Reference range-

Fasting: $70-110 \mathrm{mg} / \mathrm{dl}$

Postprandial: upto $140 \mathrm{mg} / \mathrm{dl}$

Determination of glycated haemoglobin (HbA1c)

Method - Ion exchange resin

Reference guidelines
Degree of glucose control, Total GHb, HbA1c

Normal (non-diabetic), $<7 \%<6 \%$

Near normo-glycemic, $7 \%$ to $8 \%, 6 \%$ to $7 \%$

DCCT therapeutic goal, less than $7 \%$

In good control, $8 \%$ to $9 \%, 7 \%$ to $8 \%$

Actions suggested, $9 \%$ to $11 \%, 8 \%$ to $9 \%$

Not in control, $>11 \%$, >9\%

Estimation of High Sensitive C-Reactive Protien (hs-CRP)

Method : Sandwich ELISA

Reference Range :

$<1 \mathrm{mg} / \mathrm{l}=$ Low risk of CHD.

$1-3 \mathrm{mg} / \mathrm{l}=$ Intermediate risk of CHD.

$>3 \mathrm{mg} / \mathrm{l}=$ High risk of CHD.

\section{DISCUSSION AND RESULT}

The present study was carried out among $70(n=70)$ cases of known diabetes mellitus, selected from different age group. Seventy cases of non-diabetic healthy individuals were selected as the control group. In the selection control group, (Healthy individuals) care had been taken to match the age with that of the test group (Diabetic patients). The diagnosis of diabetes mellitus was made on the basis of history, physical examination and the laboratory investigations. A fasting blood glucose level of $\geq 126 \mathrm{mg} / \mathrm{dl}$ and/or a post-prandial glucose level of $\geq 200 \mathrm{mg} / \mathrm{dl}$ were taken as the criteria to diagnose diabetes mellitus.

In the present study, it is depicted that (Table:1) diabetes mellitus affects both males and females with incidence among male is more (64.29\%) than females (35.2\%). This finding in present study is in accordance with a WHO report, which states that "In South-East Asia, an excess of male diabetics have been observed."[15]

The present study shows that the level of HbA1c was significantly raised among the diabetic patient (65.71\%), patients had an $\mathrm{HbA1c}$ values of $=7 \%, 24 \%$ of had $\mathrm{HbA} 1 \mathrm{c}$ values of $<7 \%$ when compared with their non-diabetic counter parts (Table: 2). The observations made by different workers using different sample sizes at different places in various previous studies are in agreement with the present study. Rabhar S. and his colleagues.[16] surveyed 1200 patients in Tehran and detected an abnormal band in two persons. On further inquiries, both of these individuals proved to be diabetic. Trivelli et al. (1971) showed a two-fold increase of $\mathrm{HbA1c}$ in diabetics over values found in healthy individuals. [17] Stratton IM et al. 2000: Jesudason DR et al. 2003: made the observation that "HbA1c is highly specific for identifying Diabetics in an ambulatory or in-patient setting." [18,19] Lanoe et al. (1972); Gonen et al. (1977); Graf et al. (1978); Ekkeles et al. (1978); Raheja et al. (1980); Shrivastava et al. (1984); Rohlfing CL, et al. (2002) and Nathan DM, et al. (2007) gave similar observations. [20,21,22,23,24,25,26,27]

The present study shows that the levels of HbA1c was significantly raised among diabetic patient (7.224 \pm 0.8940$)$ when compared with their control. (Table 3).

In this study, the mean value of $\mathrm{HbA} 1 \mathrm{c} \pm \mathrm{SEM}$ among the cardiovascular was found to be $17.671 \pm 3.969$, while the level in non-cardiovascular disorder was $17.314 \pm 6.371$ (Table 4). When the means were compared and the $P$ value was determined by using student ' $\mathrm{t}$ ' test it was found significant at the level of $\mathrm{p}<0.692$. 
This evidence provided up to this point clearly indicates that the level of HbA1c increases among the untreated diabetics with cardiovascular disorders.

India has the distinction of having the highest number of T2D individuals worldwide with a prevalence of $11.6 \%$ in urban populations.[28,29] Furthermore, Asian Indians are known to be at a high risk for T2D, CVD and metabolic syndrome. ${ }^{[30,31]}$

Hyperglycemia is known to stimulate the release of inflammatory cytokines from various cell types and can lead to the induction and secretion of acute-phase reactants by adipocytes. Inflammation has been the central orchestrator of atherosclerotic lesion formation, progression and eventual rupture and low-grade inflammation has been recognized as an important feature of cardiovascular disease. Therefore, markers of inflammation have been investigated for risk assessment of cardiovascular events. It is perceived that chronic low-grade inflammation as evidenced by elevated High Sensivity C-Reactive Protein (hsCRP) might potentially be a cause underlying the etiology and manifestation of type 2 diabetes (T2D), although the exact mechanisms are still not well understood. ${ }^{[32,33]}$ Additionally, hsCRP has also emerged as a powerful predictor of Cardiovascular Disease (CVD).[34] However, hsCRP levels are known to vary among populations influenced by gender, age and obesity.[35]

The Table 5 displays the comparison of mean level of hsCRP between cases suffering from diabetes mellitus and the control group. The level of hs-CRP was found to be significantly higher $(\mathrm{P}$-value $=0.000)$ in the cases suffering from diabetes mellitus (4.061 \pm 0.0876$)$ than the controls $(1.564 \pm 0.1242)$.

Both enhanced inflammation and hyperglycemia contribute to the development of atherosclerosis are found in patients with clinically advanced disease. Given the interrelation between inflammation, hyperglycemia, atherosclerosis may be speculated that $\mathrm{HbA1c}$ contribute to the cardiovascular risk.

\section{CONCLUSION AND RECOMMENDATION}

In present study, $\mathrm{HbA1c}$ was in normal range among the normal subjects and was significantly raised in diabetic patients as compared to their normal control. It was observed that among the patients with cardiovascular complications, the HbA1c was significantly increased indicating the positive correlation between cardiovascular complications.

As we know that lifestyle changes can dramatically reduce the incidence of diabetes and slow the HbA1c increase in both non-diabetic and diabetic individuals. Structural changes to our society that reduce caloric intake and increase physical activities today will lower HbA1c levels and reduce the societal rate of diabetes, consequences of diabetes tomorrow.

\begin{tabular}{|c|c|c|}
\hline & Control Group & Cases of DM (\%) \\
\hline Male & $40(57.1)$ & $45(64.2)$ \\
\hline Female & $30(42.8)$ & $25(35.2)$ \\
\hline Total & $70(100)$ & $70(100)$ \\
\hline Table 1: Distribution of Subjects according to Gender \\
\hline
\end{tabular}

The present study constitutes a small number of sample for a very limited period of time, still have good results. Further study for a longer period and larger number of samples should be done.

\begin{tabular}{|c|c|c|}
\hline & $\begin{array}{c}\text { Cases of } \\
\text { Diabetes } \\
\text { Mellitus }\end{array}$ & Percentage \\
\hline $\begin{array}{c}\text { Hb1AC more than and } \\
\text { equal 7\% }\end{array}$ & 46 & 65.7 \\
\hline Hb1AC less than 7\% & 24 & 34.2 \\
\hline Total & 70 & 100 \\
\hline
\end{tabular}

Table 2: Distribution of Cases of Diabetes Mellitus with HbA1C Level More Than Equal 7\% and Less 7\%

\begin{tabular}{|c|c|c|}
\hline & $\begin{array}{c}\text { Comparison of } \\
\text { Hb1AC } \\
\text { Level } \\
\text { (Mean } \pm \text { SD) }\end{array}$ & P value \\
\hline Control & $5.0086 \pm 1.021$ & 0.000 \\
\hline $\begin{array}{c}\text { Cases of } \\
\text { Diabetes } \\
\text { Mellitus }\end{array}$ & $7.2243 \pm 0.894$ & \multicolumn{2}{|c|}{ Table 3: Comparison of Means of HbA1C } \\
between the Cases Suffering from Diabetes \\
Mellitus and Control Group
\end{tabular}

\begin{tabular}{|c|c|c|}
\hline & $\begin{array}{c}\text { Comparison of } \\
\text { HbA1C } \\
\text { Level in } \\
\text { Percentage } \\
\text { (Mean } \pm \text { SD) }\end{array}$ & \multirow{2}{*}{ P value } \\
\hline $\begin{array}{c}\text { With Cardiovascular } \\
\text { disorder }\end{array}$ & $17.671 \pm 3.969$ & \multirow{2}{*}{0.692} \\
\cline { 1 - 2 } $\begin{array}{c}\text { Without Cardiovascular } \\
\text { disorder }\end{array}$ & $17.314 \pm 6.371$ & \\
\cline { 1 - 2 } $\begin{array}{c}\text { Table 4: Comparison of Means of HbA1C among the } \\
\text { Diabetic Patients between cases With or Without }\end{array}$ \\
\multicolumn{2}{|c|}{ Cardiovascular Disorders } \\
\hline
\end{tabular}

\begin{tabular}{|c|c|}
\hline & Comparison of hs-CRP Level (mg/L) \\
\hline Diabetic & $4.061 \pm 0.733$ \\
\hline Control & $1.564 \pm 1.039$ \\
\hline P value & 0.000 \\
\hline \multicolumn{2}{|c|}{ Table 5: Comparison of Means of hs-CRP } \\
between the Cases Suffering from Diabetes \\
Mellitus and the Control Group
\end{tabular}

\section{ACKNOWLEDGEMENT}

We would like to thank Dr. H.K. Baruah, Professor and Head, Department of Biochemistry, Katihar Medical College for his guidance and encouragement. I also thank participants for their cooperation.

\section{REFERENCES}

1. Brownlee $M$ and Cerami A. Biochemistry of the complications of diabetes mellitus. Annu rev. Biochem 1981;50:385-432.

2. Zimmet P. Diabetes epidemiology as a trigger to diabetes research. Diabetologia 1999;42:499-518.

3. Reaven G. Role of insulin resistance in human disease. Diabetes 1988;37:1595-1607. 
4. The diabetes control and complications, Trial Research Group. The effect of intensive treatment of diabetes on the development and progression of long-term complications in insulin-dependent diabetes mellitus. N Engl J Med 1993;329:977-86.

5. UK Prospective Diabetes Study (UKPDS) Group. Intensive blood-glucose control with sulphonylureas or insulin compared with conventional treatment and risk of complications in patients with type 2 diabetes (UKPDS 33). Lancet 1988;352:837-53.

6. Schillinger $M$, et al. Joint effects of CRP and glycated hemoglobin. American heart association 2003;108-2323.

7. Grundy SM, Benjamin IJ, Burke GL, et al. (1999) Diabetes and cardiovascular disease: a statement for healthcare professionals from the American Heart Association. Circulation 100, 1134-1146.

8. Reiss AB and Glass AD (2006). Atherosclerosis: immune and inflammatory aspects. J Invest Med 54, 123-131.

9. Gough PJ, Gomez IG, Wille PT and Raines EW (2006). Macrophage expression of active MMP-9 induces acute plaque disruption in apoE-deficient mice. J Clin Invest 116, 59-69.

10. Tillett WS, Francis Jr T. "Serological reactions in pneumonia with a nonprotien somatic fraction of pneumococcus." J Exp Med 1930;52:561-585.

11. Lau DC, Dhillon B, Yan H, Szmitko PE, Verma S. "Adipokines: molecular links between obesity and atherosclerosis." Am J Physiol Heart Circ Physiol 2005;288(5):H2031-41.

12. Yasojima K, Schwab C, McGeer EG. Generation of C-reactive protein and complement components in atherosclerotic plaques. Am J Pathol 2001;158(3):1039-51.

13. Jabs WJ, Theissing E, Nitschke M, Bechtel JE, Bartels C. Local generation of $\mathrm{C}$-reactive protein in diseased coronary artery venous bypass grafts and normal vascular tissue. Circulation 2003;108(12):1428-31.

14. Calabro P, Willerson JT, Yeh ET. Inflammatory cytokines stimulated C-reactive protein production by human coronary artery smooth muscle cells. Circulation 2003;108(16):1930-2.

15. WHO (1980). Tech. Rep. Ser: No. 646. Park.

16. Trivelli LA, Ranny HN, Lai HT (1971): Haemolobin components in patients with diabetes mellitus. N Engl J Med 284, 353-357.

17. Festa A, D'Agostin Jr, Tracy RP, Haffner SM: elevated levels of acute phase proteins and plasminogen activator inhibitor- 1 predict the development of Type 2 diabetes: the insulin resistance atherosclerosis study. Diabetes 51:1131-1137, 2002.

18. Stratton IM, Adler AI, Neil HA, et al. (2000) Association of glycemia with macrovascular and microvascular complications of type 2 diabetes (UKPDS 35): prospective observational study. BMJ; 321:405-12.

19. Jesudason DR, Dunstan K, Leong D, Wittert G. (2003): Macrovascular risk and diagnostic criteria for type 2 diabetes: implications for the use of FPG and HbA1c for cost-effective screening. Diabetes care; 26:485-90.
20. Lanoe R, Saria J, Tuibult N, et al. (1972): HbA1c concentrations and contest rest results in insulin dependent diabetes. Lancet. 2, 1156-57; (Quoted by Watkins, et al.) The medical Annual, 5-7;1979/80.

21. Gonen B, Rubenstein AH, Rochman H, Tanga S, Morcoitz DL (1977): Haemoglobin A1. An indicator of the metabolic control of diabetic patients. Lancet II, 734-737.

22. Graf RJ, Halter JB, Porte D (1978). Glycosylated haemoglobin in normal subjects and subjects with maturity onset diabetes: Evidence for a saturable system in men. Diabetes; 27:834-39.

23. Ekkeles RS, WNJ Humbly J (1978): Haemoglobin A, Blood glucose and high density lipoprotein in cholesterol in insulin-requiring diabetes. Lancet 9, 547-49.

24. Raheja BS, Lyer PD, Bhargava D and Krishnaswamy PR (1980): GHb; its value in the management of diabetes mellitus. Jr Assoc Phys Ind 29;609-612.

25. Srivastava BN, Vidya VV, Bodkha PR, Hotchandani BR (1984): GHb in diabetes mellitus, Jr Assoc Phys Ind32(i);36.

26. Rohlfing CL, Wiedmeyer HM, Little R, England JD, Tennill A, Goldstein DE:(2002). Defining the relationship between plasma glucose and HbA1c in the Diabetes Control and Complications Trial. Diabetes Care 25:275-278.

27. Nathan DM, Turgeon H, Regan S (2007): Relationship between glycated haemoglobin levels and mean glucose levels over time. Diabetologia 50:2239-2244.

28. Barzilay JI, Abraham L, Heckbert SR, Cushman M, Kuller LH, Resnick HE, Tracy RP: The relation of markers of inflammation to the development of glucose disorders in the elderly: the Cardiovascular Health Study. Diabetes 50:2384-2389, 2001.

29. Ford ES: Body mass index, diabetes and C-reactive protein among US Adults. Diabetes Care 22:1971-1977, 1999.

30. Goldberg RB: Cardiovascular disease in diabetic patients. Med Clin North Am 84:81-93, 2000.

31. WuT, Dorn JP, Donahue RP, Sempos CT, Trevisan M: Associations of serum C-reactive protein with fasting insulin, glucose and glycosylated hemoglobin. Am J Epidemiol 155:65-71, 2002.

32. Abdelmouttaleb I, Danchin N, Ilardo C, Aimone-Gastin I, Angioi M, Lozniewski A, Loubinoux J, Le Faou A, Gueant JL: C-reactive protein and coronary artery disease: additional evidence of the implication of an inflammatory process in acute coronary syndromes. Am Heart J 137:346-351, 1999.

33. Ridker PM, Glynn RJ, Hennekens $\mathrm{CH}$ : C reactive protein adds to the predictive value of total and HDL cholesterol in determining risk of first myocardial infarction. Circulation 97:2007-2011, 1998.

34. Ridker PM, Stampfer MJ, Rifai N: Novel risk factors for systemic atherosclerosis: a comparison of C-reactive protein, fibrinogen, homocysteine, lipoprotein(a), and standard cholesterol screening as predictors of peripheral arterial disease. JAMA 285:2481-2485, 2001.

35. Pradhan AD, Manson JE, Rifai N, Buring JE, Ridker PM: Creactive protein, interleukin- 6 , and risk of developing type 2 diabetes mellitus. JAMA 286:327-334, 2001. 